\title{
Obama calls on Congress to fully fund Zika response
}

\author{
Michael McCarthy \\ Seattle
}

After a White House briefing with his administration's top health experts on 20 May, US president Barack Obama renewed his call for Congress to fully fund his request for $\$ 1.9$ billion ( $£ 1.31 \mathrm{~b} ; € 1.7 \mathrm{~b}$ ) in emergency funding to combat the spread of the Zika virus in the US and abroad. Obama made his first request for the funds in February. ${ }^{1}$

Earlier in the week the Senate, in a compromise between Democrats and Republicans, voted to appropriate about half the president's request, $\$ 1.1 \mathrm{~b}$. The House of Representatives, however, voted to provide far less, just $\$ 622 \mathrm{~m}$ or about a third of what the White House said was needed.

Over the past several months, the administration has shifted funds from other programs to support the government's response, but the president said that full funding of his request was urgently needed to pay for effective mosquito control, the development and distribution of more effective diagnostic tests, and the development of a vaccine. "We didn't just choose the $\$ 1.9 \mathrm{~b}$ from the top of our heads. This was based on public health assessments of all the work that needs to be done," the president said.

House conservatives, however, said that they would not support a bill that would add to the deficit and called on the administration to use unspent funds allocated to fight the Ebola outbreak in west Africa. Administration officials said that those funds were needed for ongoing projects aimed at reducing the risk of another outbreak. With the mosquito season beginning in the southern US, the Senate and House were facing increasing pressure to pass a final funding package. The White House indicated that the president would accept the Senate bill but that he would veto the House bill.

In its most recent update, US Centers for Disease Control and Prevention (CDC) reported that, as of 18 May, there had been 544 reported travel associated cases of Zika virus infection in the US. None of the cases were acquired locally through mosquito bites, but 10 were the result of sexual contact with a partner who had contracted the infection while traveling abroad. In the US territories, however, 836 cases were reported, predominantly in Puerto Rico. All but four of these cases were locally acquired.

Although Zika infection was thought to be a relatively mild disease - causing fever, rash, joint pain, and conjunctivitis in a minority of cases - it has now been linked with neurological complications, including Guillain-Barré Syndrome, and severe birth defects, including microcephaly, when an infection occurs during pregnancy. Of the infections reported to the CDC, 157 in the US and 122 in the territories have been in pregnant women. To date, fewer than a dozen of the pregnancies have had adverse outcomes, including stillbirths and microcephaly, the CDC said, but the agency did not provide specific details about the cases. Most of the pregnancies were ongoing.

Obama said that care of a child with a severe birth defect like microcephaly could cost up to $\$ 10 \mathrm{~m}$ over the lifetime of the child. "It doesn't take a lot of cases for you to get to $\$ 1.9 \mathrm{~b}$," the president said. "Why wouldn't we want to make that investment now?"

According to $\mathrm{WHO}$, since the virus was identified in Brazil in 2015, 45 countries and territories in the Americas had reported locally acquired infections, and it was confirmed last week that the strain responsible for the outbreak in the Americas had reached the African island of Cape Verde, raising concerns that the virus would soon appear on the African mainland.

WHO said that the virus was expected to reach Europe by late spring with the island of Madeira and north eastern coast of the Black Sea being at the greatest risk. ${ }^{2}$ Another 18 European countries are at moderate risk of outbreaks, WHO said. These were, in order of likelihood: France, Italy, Malta, Croatia, Israel, Spain, Monaco, San Marino, Turkey, Greece, Switzerland, Bulgaria, Romania, Slovenia, Georgia, Albania, Bosnia and Herzegovina, and Montenegro.

McCarthy M. US health officials press Congress for Zika funds. BMJ 2016:352:i1545. 2 Gulland A. WHO warns of risk of Zika virus in Europe. BMJ 2016;353:i2887. doi:10.1136/ bmj.i2887 pmid:27207768.

Published by the BMJ Publishing Group Limited. For permission to use (where not already granted under a licence) please go to http://group.bmj.com/group/rights-licensing/ permissions 